Contents available at: Sri Lanka Journals Online

\title{
Evaluation of Some Potential Protocols to Extract DNA from Paddy Soil
}

\author{
T.D. Ranasinghe ${ }^{1}$, D.M. De Costa ${ }^{2 *}$, R.S. Dharmakeerthi ${ }^{3}$ \\ ${ }^{1}$ Postgraduate Institute of Agriculture, University of Peradeniya, 20400, Sri Lanka \\ 2 Department of Agricultural Biology, Faculty of Agriculture, University of Peradeniya, Peradeniya, 20400, Sri Lanka \\ ${ }^{3}$ Department of Soil Science, Faculty of Agriculture, University of Peradeniya, Peradeniya, 20400, Sri Lanka
}

ARTICLE INFO
Article history:
Received: 15 August 2020
Revised version received: 10 February
2021
Accepted: 02 April 2021
Available online: 01 October 2021

\section{Keywords:}

Direct DNA extraction

Downstream application

Microbial community analyses

\section{Citation:}

Ranasinghe, T.D., De Costa D.M., and Dharmakeerthi, R.S. Evaluation of some potential protocols to extract DNA from paddy soil. Tropical Agricultural Research, 32(4): 409-417.

DOI: http://doi.org/10.4038/tar.v32i4.8509

Ranasinghe, T.D.

https://orcid.org/0000-0001-7955-3908

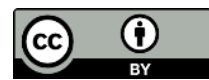

\section{ABSTRACT}

Isolation of DNA from environmental samples is a crucial step in microbial community analyses through molecular methods. The present study was conducted to evaluate a DNA extraction protocol from paddy soil with a comparison on quality, quantity and integrity of the isolated DNA and to determine the suitability of extracted DNA for downstream applications in microbial community analyses. Three protocols (i.e. $\mathrm{PEG} / \mathrm{NaCl}$, Mannitol/CTAB and Sodium Phosphate Buffer) used for the extraction of DNA from different types of soil were attempted on paddy soil. The quality and quantity of the extracted genomic DNA was quantified spectrophotometrically and integrity was checked by gel electrophoresis. The efficiency of DNA extraction by the three protocols was compared with a commercial soil DNA extraction kit (Norgen's Soil DNA Isolation Plus Kit). Further, quality of the extracted DNA for PCR amplification was assessed using universal primer pairs for bacteria and fungi. DNA extracted using PEG/NaCl method resulted in the highest DNA concentration, while the highest purity was recorded by the DNA extracted by Mannitol/CTAB method $(A 260 / A 280=1.61$ and A260/A230 = 1.15). Expected PCR products targeting $16 \mathrm{~s}$ rDNA and ITS regions were obtained from the DNA samples extracted by Mannitol/CTAB method. Therefore, Mannitol/CTAB method used in the present study is suitable to extract high-quality DNA from paddy soil for molecular microbial studies.

\footnotetext{
*Corresponding author: devikadecosta@gmail.com
} 


\section{INTRODUCTION}

Soil is an essential non-renewable resource where essential functions needed for life on earth are carried out. Most of these functions depend on microorganisms that inhabit the soil. It is believed that a gram of soil may contain possibly thousands of different species (Knietsch et al., 2003). Among them, diverse microflora has been identified for its beneficial functions in the soil-plant system. They perform various catabolic activities and are involved in primary production, nutrient recycling, etc. In addition, their interactions with plant root systems play key roles in several other functions, such as decomposition of organic matter, nutrient balancing, and pathogen suppression (Dimitrov et al., 2017). However, the fundamental understanding of the diversity and ecology of these microbial communities has been hampered due to the inability of growing most of the microbes under laboratory conditions (Philippot et al., 2011).

In Sri Lanka, the highest extent of land $(1,254,000$ ha) is cultivated (both Yala and Maha season) with Paddy (Department of Census and Statistics, 2015). Hence, paddy soils represent the principal agricultural system in Sri Lanka. Fertile soil provides essential nutrients for crop growth and even more supports for the diverse and active microbial community. Therefore, knowledge of this microbial community structure in paddy soils can improve the understanding of soil processes and microbial functions in rice-based cropping system (Islam et al., 2009).

Introduction of culture-independent techniques, such as analyses of microbial DNA, has upgraded environmental microbiology, resulting in novel information on unculturable microbial populations. Thus, the traditional taxonomy based morpho-physiological and biochemical studies have to be replaced by the DNA based phylogenetic studies of microorganisms (Delmont et al., 2011). Therefore, different methods need to be tested to determine their effectiveness upon soil microbial assessments and developed userfriendly, standardized protocols with reduced time durations (Plassart et al., 2012). As cultureindependent approaches are more advantageous, numerous protocols have been developed to extract DNA from different soils in the world. However, the purity of the DNA extracted from the soil often depends on its composition and found unsatisfactory, especially in soils that are rich in humic compounds such as paddy soils. In this context, significant efforts need to be devoted to optimize soil DNA extraction protocols to obtain targeted results. However, there is no information published yet on paddy soil metagenomics in Sri Lanka, despite the fact that it has been used as the prime tool in the paddy soil microbiological research. Thus, the present study was carried out to compare and evaluate direct DNA extraction protocols which can be used for metagenomics and other downstream molecular applications.

\section{METHODOLOGY}

\section{Sample Collection}

Soil samples were collected from a paddy field located at Mihinthale, Anuradhapura, Sri Lanka in September 2019. The sampling was done by collecting soils from nine randomly selected points within the field at $0-10 \mathrm{~cm}$ depth using a $1.25 \mathrm{~cm}$ diameter soil core. Samples from the field were then combined to form one composite sample and stored at $-20^{\circ} \mathrm{C}$ until used in analyses. Different soil parameters including $\mathrm{pH}$, electrical conductivity (EC), total nitrogen $(\mathrm{N})$, phosphorus $(\mathrm{P})$, potassium $(\mathrm{K})$, organic carbon $(\mathrm{OC})$ and organic matter $(\mathrm{OM})$ content of the sample were tested (Table 1).

Table 1. Selected properties of the tested paddy soil sample. The values are means of three replicates.

\begin{tabular}{lr}
\hline Soil parameter & Value* $^{*}$ \\
\hline $\mathrm{pH}$ & $6.82 \pm 0.062$ \\
$\mathrm{EC}(\mathrm{ds} / \mathrm{m})$ & $0.946 \pm 0.910$ \\
$\mathrm{~N}(\mathrm{~g} / \mathrm{kg})$ & $0.99 \pm 0.034$ \\
$\mathrm{P}(\mathrm{ppm})$ & $18.53 \pm 0.270$ \\
$\mathrm{~K}(\mathrm{mg} / \mathrm{kg})$ & $180.95 \pm 4.760$ \\
OM $(\%)$ & $1.70 \pm 0.046$ \\
OC $(\%)$ & $0.99 \pm 0.027$ \\
\hline
\end{tabular}

\section{Extraction of Soil DNA}

Three different protocols were tested to extract total DNA from paddy soil and compared with commercially available DNA extraction kit. The protocols are described briefly as follows.

\section{Mannitol/CTAB (Cetyl trimethyl ammonium bromide) method}

An extraction protocol described by Fatima et al. (2014) was followed with slight modifications. A 1 $\mathrm{g}$ of the composite paddy soil sample was ground 
with liquid nitrogen $\left(\mathrm{LN}_{2}\right)$ using $5 \mathrm{~mL}$ of $120 \mathrm{mM}$ phosphate buffer saline at $\mathrm{pH} 7.4$ and shaking at $150 \mathrm{rpm}$ for $10 \mathrm{~min}$ at room temperature. The resulted in suspension was centrifuged at 7,000 rpm for $10 \mathrm{~min}$. The pellet was rewashed using phosphate buffer saline and suspended in $10 \mathrm{~mL}$ of DNA extraction buffer containing $1 \mathrm{M}$ Tris- $\mathrm{HCl}$ (pH 8.0), $5 \mathrm{M} \mathrm{NaCl}, 0.5 \mathrm{M}$ EDTA (pH 8.0), 10\% CTAB, $10 \%$ SDS, and $0.5 \mathrm{M}$ mannitol. The suspension was incubated for $1 \mathrm{~h}$ at $65^{\circ} \mathrm{C}$ with occasional stirring at $250 \mathrm{rpm}$. The supernatant was collected after centrifuging the suspension at $8000 \mathrm{rpm}$ for $10 \mathrm{~min}$ at room temperature. Thereafter, it was extracted with an equal volume of Phenol: Chloroform: Isoamyl alcohol (25:24:1) by centrifugation at $12,000 \mathrm{rpm}$ for $10 \mathrm{~min}$ at room temperature. The aqueous fraction was taken and mixed with $1 / 10^{\text {th }}$ volume of $3 \mathrm{M}$ sodium acetate (pH 5.2) and 2 volumes of $70 \%$ chilled ethanol at $4{ }^{\circ} \mathrm{C}$. Finally, the pellet was recovered by centrifugation at $12,000 \mathrm{rpm}$ for 10 min at $65^{\circ} \mathrm{C}$ and dissolved in $25 \mu \mathrm{L}$ TE buffer $(10$ mM Tris, 1 mM EDTA pH 8) and stored at $-20{ }^{\circ} \mathrm{C}$ for future use.

\section{Polyethylene Glycol (PEG)/NaCl method}

The extraction of DNA was performed using a protocol described in Avinash et al. (2016) with little modifications. A $1 \mathrm{~g}$ of composite paddy soil sample was mixed with $20 \mathrm{~mL}$ of extraction buffer (1 M NaCl, 1\% PEG $8000(\mathrm{w} / \mathrm{v}$ ) at $\mathrm{pH} 9.2)$ and vortexed for $30 \mathrm{~s}$. It was centrifuged at 5,000 rpm for $5 \mathrm{~min}$ at room temperature and the supernatant was discarded. A volume of $10 \mathrm{~mL}$ of extraction buffer was re-added to the pellet and centrifuged at $15,000 \mathrm{rpm}$ for $20 \mathrm{~min}$ at room temperature. The received pellet was resuspended in $500 \mu \mathrm{L}$ of suspension buffer $(10 \mathrm{mM}$ Tris- $\mathrm{HCl}, 10 \%$ sucrose, $50 \mathrm{mM}$ EDTA, $50 \mathrm{mM} \mathrm{NaCl}$ at $\mathrm{pH}$ 8.0). $20 \mu \mathrm{L}$ of freshly prepared lysozyme (20 $\mathrm{mg} / \mathrm{mL}$ ) was added and incubated at room temperature for $45 \mathrm{~min}$. Further, $6 \mu \mathrm{L}$ of proteinase $\mathrm{K}$ was added and incubated at $55^{\circ} \mathrm{C}$ for another $45 \mathrm{~min}$. Next, $50 \mu \mathrm{L}$ of $20 \%$ SDS was added and incubated with intermittent mixing at $65^{\circ} \mathrm{C}$ for $45 \mathrm{~min}$. The samples were centrifuged at $15,000 \mathrm{rpm}$ for $5 \mathrm{~min}$ at $20{ }^{\circ} \mathrm{C}$. A $200 \mu \mathrm{L}$ of suspension buffer and $50 \mu \mathrm{L}$ of $20 \%$ SDS were added. The samples were subjected to vortexing for $3 \mathrm{~min}$ and centrifuged at 15,000 rpm for $5 \mathrm{~min}$ at $20^{\circ} \mathrm{C}$. Then, $1 / 10$ th volume of $2.5 \mathrm{M}$ potassium acetate $(\mathrm{pH}$ 8.0) was added and the tubes were centrifuged at lower $(7,000 \mathrm{rpm})$ and higher speeds $(15,000 \mathrm{rpm})$ respectively, at room temperature for $5 \mathrm{~min}$. The supernatant was taken, an equal volume of isopropanol was added and then it was centrifuged at $15,000 \mathrm{rpm}$ at $4{ }^{\circ} \mathrm{C}$ for $20 \mathrm{~min}$. The DNA pellet was washed with $70 \%$ ethanol and air-dried. The pellet was dissolved in $25 \mu \mathrm{L}$ of TE buffer ( $\mathrm{pH} 8.0$ ) and stored at $-20^{\circ} \mathrm{C}$.

\section{Sodium Phosphate Buffer (SPB) method}

DNA was extracted using the protocol described in Tsai and Olson (1991) with slight modifications. A $1 \mathrm{~g}$ of composite paddy soil was mixed with $2 \mathrm{ml}$ of $120 \mathrm{mM}$ Sodium Phosphate Buffer (SPB) $(\mathrm{pH}$ 8.0) and shaken on a platform shaker at $250 \mathrm{rpm}$ for $15 \mathrm{~min}$ at room temperature. The samples were centrifuged at $8,000 \mathrm{rpm}$ for $10 \mathrm{~min}$ and the supernatant was discarded. The pellet was washed with phosphate buffer. An aliquot of $2 \mathrm{~mL}$ of lysis solution I $(0.15 \mathrm{M} \mathrm{NaCl}, 0.1 \mathrm{M}$ disodium EDTA at pH 8.0) containing $20 \mathrm{mg} / \mathrm{ml}$ of lysozyme was added to the sample and incubated at $37{ }^{\circ} \mathrm{C}$ for $2 \mathrm{~h}$ with intermittent mixing. Then, lysis solution II $(0.5 \mathrm{M}$ Tris- $\mathrm{HCl}, 0.1 \mathrm{M} \mathrm{NaCl}, 10 \%$ SDS $\mathrm{pH}$ 8.0) was added and freeze-thawed the tubes three times at $-20^{\circ} \mathrm{C}$ and $65^{\circ} \mathrm{C}$ respectively for the complete extraction of DNA from soil microbes. The samples were centrifuged at 8,000 rpm for 15 min, the supernatant was taken and equal volumes of chloroform: isoamyl alcohol (24:1) were added. The samples were centrifuged at $10,000 \mathrm{rpm}$ for $5 \mathrm{~min}$ and the aqueous fraction was collected. To that, $0.6 \% \mathrm{v} / \mathrm{v}$ isopropanol was added and incubated at room temperature for $1 \mathrm{~h}$. Then, centrifugation was done at $12,000 \mathrm{rpm}$ for $20 \mathrm{~min}$. The top layer was collected and washed with $70 \%$ ethanol and air-dried the pellet at room temperature. The pellet was re-suspended in 25 $\mu \mathrm{L}$ of TE buffer ( $\mathrm{pH} 8.0)$ and stored at $-20^{\circ} \mathrm{C}$.

\section{DNA extraction kit (Norgen's kit)}

Commercially available Norgen's Soil DNA Isolation Plus Kit (Biotech Corporation, 3430 Schmon Parkway Thorold, ON, Canada) was used to check the efficiency of DNA extraction. Paddy soil DNA was extracted following manufacturer's instructions.

\section{Assessment of Quantity, Quality, and Integrity of Extracted DNA}

Total DNA quantity $(\mathrm{ng} / \mu \mathrm{L})$ and quality (A260/A230 and $A_{260 / A 280}$ ratios) were measured using a NanoDrop 1000 spectrophotometer (Shimadzu, Japan). Samples of extracted DNA were also examined by agarose gel electrophoresis. The bands were separated on $0.8 \%(\mathrm{w} / \mathrm{v})$ agarose gel containing ethidium bromide. The gel images were visualized under ultraviolet (UV) light to observe their intact nature. 


\section{PCR Amplification}

PCR amplification was performed to test their suitability for downstream applications. In the present study, universal bacterial and fungal primer sets were used. Bacterial 16s rDNA regions were amplified using forward primer 27f (5'AGAGTTTGATCCTGGCTCAG-3') and reverse primer 1492r (5'-GGTTACCTTGTTA CGACTT-3'). Amplifications were carried out under the following conditions: $95{ }^{\circ} \mathrm{C}$ for $5 \mathrm{~min}, 35$ cycles of $95{ }^{\circ} \mathrm{C}$ for $1 \mathrm{~min}, 53{ }^{\circ} \mathrm{C}$ for $30 \mathrm{~s}, 72{ }^{\circ} \mathrm{C}$ for $1.5 \mathrm{~min}$, $72{ }^{\circ} \mathrm{C}$ for $7 \mathrm{~min}$. Fungal communities were analyzed using forward primer ITS1f (5'CTTGGTCATTTAGAGGAAGTAA-3') and reverse primer ITS4r (5'-TCCTCCGCTTATTGATATGC-3') with the following conditions: $95{ }^{\circ} \mathrm{C}$ for $5 \mathrm{~min}$; followed by 35 cycles of $95{ }^{\circ} \mathrm{C}$ for $1 \mathrm{~min}, 55^{\circ} \mathrm{C}$ for $30 \mathrm{~s}$ and $72{ }^{\circ} \mathrm{C}$ for $1 \mathrm{~min}$; then a final elongation of $72{ }^{\circ} \mathrm{C}$ for $5 \mathrm{~min}$. The amplified products were separated using $1.5 \%$ agarose gel under UV illumination using Lambda DNA cut with EcoRI/Hindlll and the $100 \mathrm{bp}$ size markers for bacteria and fungi respectively.

\section{RESULTS AND DISCUSSION}

The efficiency of DNA extraction depends on the biological material used and the protocol followed (Chen et al., 2010). Every DNA extraction protocol consists of a technique to lyse the cells, solubilize the DNA and enzymatic/chemical methods to remove other contaminants. However, a good protocol that can be used to extract DNA should be cost-effective, efficient in terms of time and labor, yield the most DNA possible while limiting the amount of DNA degraded (Chen et al., 2010).

Other than the DNA degradation and incomplete cell lysis, soil DNA extraction procedures also will be influenced by different parameters like sorption of DNA to soil surfaces and extraction of humic contaminants. Thus, proper lysis of microbes and inhibitor-free DNA are major requirements for any soil DNA extraction protocol used for metagenomic studies (Gu et al., 2005). For more effective cell lysis, mechanical treatment should be followed rather than chemical ones (More et al., 1994 and Fatima et al., 2014). According to Frostegard et al. (1999), proper grinding of selected sample ruptures the cell wall and thereby facilitates the easy releasing of cellular DNA from the inner compartment of the cell. DNA which is used for downstream application should be free from PCR inhibitors or low in concentration in order to avoid interferences with the enzymatic reactions (Fatima et al., 2014).

With reference to extraction of DNA from soil, Zhou et al. (1996) and Saens et al. (2019) reported that soil properties have a significant effect on the efficiency of cell lysis, the amount of DNA loss and the purity of the DNA extract. Moreover, Islam et al. (2012) reported that the efficiency of soil microbial DNA extraction often depends on soil qualities, such as soil electrical conductivity, soil texture, inorganic carbon, and nitrogen content but not with $\mathrm{pH}$ and organic carbon content. However, microorganisms strongly bind with soil particles through a various binding mechanisms that reduce access to the whole microbial community. Robe et al. (2003) reported that organic matter content mainly determined by the organization of micro- and macro-aggregates and microorganisms are heterogeneously distributed inside micro-aggregates and in macro-porosities outside micro-aggregates. Hence, it will be one of the major source of inhibitors that can be coextracted with soil microbial DNA (Courtois et al., 2001).

The soil used in current study has reported high amount of $\mathrm{K}$ and $\mathrm{P}$ with low amount of $\mathrm{N}, \mathrm{OM}$ and OC (Table 1). However, the samples used in present study were taken from one defined location in order to avoid the effect of soil type for DNA extraction.

\section{DNA Yield}

In the present study, different extraction protocols were tested to separate microbial community DNA from paddy soils. According to the results (Table 2), DNA extracted by PEG/NaCl method yielded relatively high concentration of DNA than the other tested protocols. The differences of yielded DNA could be due to the differences in protocols followed, especially with the methods used to lyse the cells (Table 3). Several studies have reported that, noticeable difference on DNA yield could be due to differences of the lysis methods used (Zhang et al., 2003; Islam et al., 2012). The current study also suggests that the lysis can be an important factor that can be influenced on DNA yield. In PEG/NaCl method, the enzymatic digestion lysozyme and high concentrated SDS (Li et al., 2011) may effectively break up the cell wall of the microorganism to release DNA easily. On the other hand, SPB method produced a comparatively low quantity of DNA. Islam et al. (2012) and Shao et al. (2012) reported that repeated freezing-thawing steps can cause a certain degree of damage to nucleic acids. Especially they reported that, DNA larger than. 
Table 2. Concentrations and purity of extracted DNA from paddy soils as determined by spectrophotometrically

\begin{tabular}{lrlllc}
\hline \multirow{2}{*}{\multicolumn{1}{c}{ Protocol }} & \multicolumn{2}{c}{ DNA quantity } & \multicolumn{2}{c}{ DNA purity } & \multirow{2}{*}{$\begin{array}{c}\text { DNA extraction } \\
\text { efficiency (\%)* }\end{array}$} \\
\cline { 2 - 5 } & $\mathbf{g} / \boldsymbol{\mu L}$ & $\boldsymbol{\mu g} / \mathbf{g}$ of soil & $\mathbf{A}_{\mathbf{2 6 0}} / \mathbf{A}_{\mathbf{2 8 0}}$ & $\mathbf{A}_{\mathbf{2 6 0}} / \mathbf{A}_{\mathbf{2 3 0}}$ & 69.02 \\
\hline Mannitol/CTAB method & 281.47 & 7.04 & 1.61 & 1.15 & 93.24 \\
PEG/NaCl method & 380.51 & 9.51 & 0.89 & 0.67 & 63.82 \\
SPB method & 260.18 & 6.51 & 1.11 & 0.87 & - \\
Norgen's kit & 408.14 & 10.20 & 1.72 & 1.11 & - \\
\hline
\end{tabular}

* Efficiency of DNA extraction was calculated with reference to the DNA quantity by Norgen's kit; (DNA quantity obtained by a given method / DNA quantity obtained by Norgen's kit\}x100

Table 3. Differences of major steps involved in three protocols

\begin{tabular}{llll}
\hline Step & Mannitol/CTAB method & PEG/NaCl method & SPB method \\
\hline Cell lysis & & & \\
1. Mechanical & - & - & Freezing \& thawing \\
2.Chemical & Liquid $\mathrm{N}_{2}$ & $20 \% \mathrm{SDS}$ & $10 \% \mathrm{SDS}$ \\
& $10 \% \mathrm{SDS}$ & $\mathrm{NaCl}$ & $\mathrm{NaCl}$ \\
& $\mathrm{NaCl}, \mathrm{CTAB}$ & Sucrose & \\
& Mannitol & & Lysozyme \\
3.Enzymatic & - & Lysozyme & \\
\hline Purification & Phenol & Proteinase $\mathrm{K}$ & Chloroform \\
& Chloroform & PEG & Isoamyl alcohol \\
& Isoamyl alcohol & Sodium acetate & Isopropanol \\
\hline Precipitation & Sodium acetate & Isopropanol & $70 \%$ ethanol \\
\hline
\end{tabular}

$100 \mathrm{~kb}$ in size is highly sensitive to degradation due to freezing and thawing. This may be the reason of having low quantity of DNA extracted by SPB method which involved many freeze/thaw cycles

\section{DNA Purity}

The purity of the extracted DNA is important for PCR amplification and other downstream applications such as metagenomic studies, hybridization, denaturing gradient gel electrophoresis, fingerprinting, and sequencing. Therefore, the present study investigated the purity of the extracted DNA. The humic acids, phenol, and other aromatic compounds are absorbed in $230 \mathrm{~nm}$ whereas DNA at $260 \mathrm{~nm}$ and protein at $280 \mathrm{~nm}$. Therefore, $\mathrm{A}_{260 / \mathrm{A} 230}$ and $\mathrm{A}_{260 / \mathrm{A} 280}$ ratios are used as the indicators of the quality DNA. A pure sample of DNA has the $\mathrm{A}_{260 / \mathrm{A} 280}$ ratio as 1.8 and the $\mathrm{A}_{260 / \mathrm{A} 230}$ ratio as 2.0 whereas DNA preparation that is contaminated with protein and humic acids will have an A260/A280 and A260/A230 ratios lowers than 1.8 and 2.0 respectively (Sambrook et al., 1989). In the present study, absorbance ratios of DNA extracted by all three direct DNA extraction protocols were reported below 1.7 (Table 2), which reflects the co-extraction of contaminants such as proteins, phenolic compounds, or humic acid. DNA extracted using Norgen's kit has resulted in a value closest to 1.8 indicating the purity of extracted DNA in comparison to the other three methods. In comparison to the Norgen's kit, Mannitol/CTAB method and SPB method, both ratios given by $\mathrm{PEG} / \mathrm{NaCl}$ method were surprisingly low, suggesting that $\mathrm{PEG} / \mathrm{NaCl}$ method was less effective in removing the contaminations such as humic acids, phenols, and proteins. Since humic acid contains the same charge and size characteristics similar to that of DNA, it exhibits absorbance at both 230 and at $260 \mathrm{~nm}$ and hence interferes in quantization of DNA (Fatima et al., 2014). Although in PEG/NaCl method PEG is used to remove humic acids, expected results were not obtained. Fatima et al. 
(2014) also reported that the protocol consists of mannitol and CTAB was the best among tested protocols, which is on par with the findings of the present study. Thereby, grinding soil samples with liquid nitrogen may provide an excellent mechanical force for cell breakup. Moreover, mannitol with sodium chloride within the lysis buffer also promoted disruption of cells and extracted humic acid and other organic contaminants, the presence of which would have otherwise inhibited PCR reaction. Further, CTAB and mannitol also supported to stabilize the enzymes (Fatima et al., 2014). Another advantage of this protocol is the inclusion of Phenol, Chloroform and Isoamyl alcohol to minimize the additional purification steps and remove proteins and humic acids effectively. This has previously been used as a purifying agent in many other studies of soil DNA extraction (Satyanarayana et al., 2017).

\section{DNA integrity}

According to Figure 1, it is evident that all three protocols resulted in intact genomic DNA. However, intensity of the genomic DNA band resulted in by SPB method was relatively low and could be due to low amount of DNA yielded by the method (Table 2).

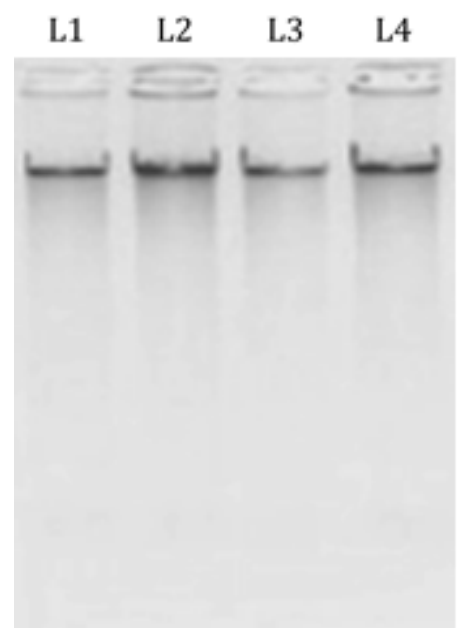

Figure 1: Comparison of genomic DNA extracted by three direct extraction protocols and Norgen's kit; L1 - DNA extracted from Mannitol/CTAB method, L2 - DNA extracted from PEG/NaCl method, L3 - DNA extracted from SPB method, L4 - DNA extracted from Norgen's kit

\section{PCR amplification}

Humic acids are one of the most common inhibitors existing in environmental soils. Several studies revealed that the humic acids can inhibit the PCR at the amplification steps or have adverse effects on DNA extraction via sequestration (Islam et al., 2012; Knauth et al., 2013). Humic substances chelate the $\mathrm{Mg}^{2+}$ ions which required for the activity of Taq polymerase, restriction enzymes and ligases (Devi et al., 2015).

The present study tested $27 \mathrm{f}$ and $1492 \mathrm{r}$; 16 s rDNA universal primers which have been widely used for amplifying bacterial ribosomal genes in several studies (Chen et al., 2010 and Devi et al., 2015). According to Figure 2, DNA extracted using Mannitol/CTAB method and by the commercial kit had given expected band ( 1500 bp). This could have happened due to low purity of the DNA of the other two methods (Table 2), which ultimately leads to inhibit PCR. Therefore, addition of more purification steps could improve the results. Similarly, as shown in the Figure 2, expected band $(\sim 750)$ was resulted in the DNA sample extracted via Mannitol/CTAB method while others were not (DNA extracted by the commercial kit was not included). This could be due to low purity as previously mentioned. ITS 1 and ITS 4 primer set is broad spectrum. However, some research studies suggested that use of ITS 1 and 2 primers will be more effective in amplifying fungi due to their specificity (Op De Beeck et al, 2014). This may be the reason not having sharp band for DNA extracted using Mannitol/CTAB method. Thus, in addition to adding of more purification steps, use of more effective and specific primer sets also could improve the results. Liu et al. (2015) and Yi et al. (2019) reported that the abundance of bacterial and fungal community is differing with the depth of paddy soil. Further, they have revealed that bacterial community is higher in surface layers than the fungal community and when increasing the depth of soil fungal community getting lower. Wichern et al. (2020) reported that, paddy systems consist with periods of water saturation/ anaerobic and periods of aerobic conditions, which can be both affected by salinization.

However, after flooding the paddy field, water saturation might result in a dilution of accumulated salts and when water is lost from the system, salt accumulation. It is known that soil microorganisms are affected by both, increased soil salinity and reduced oxygen availability. Further, Wichern et al. (2020) have reported that fungal ITS1 was significantly affected by water content in soil and there was a tendency of reduced fungal contents at higher water levels and a lower fungi-to-bacteria ratio. 


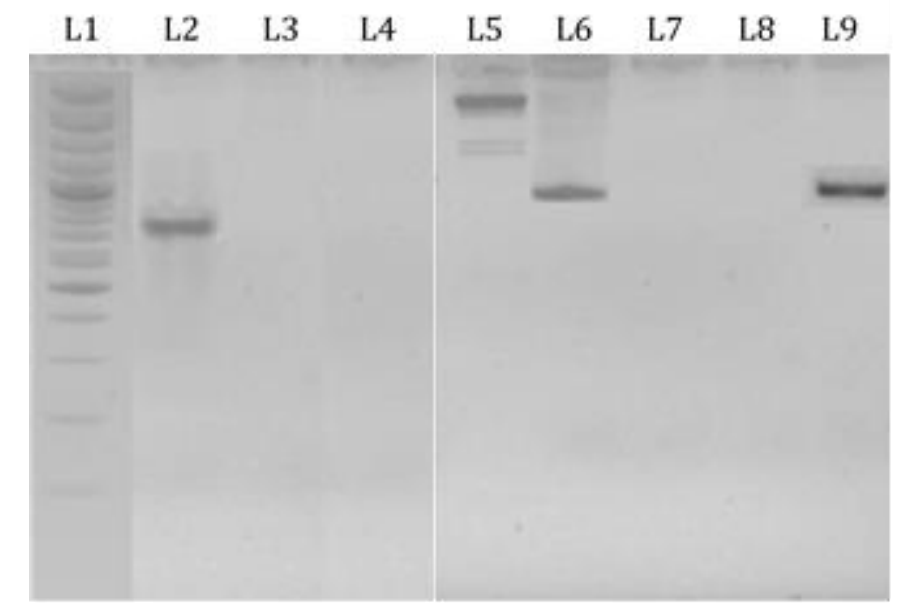

Figure 2. Gel electrophoresis of PCR products amplified with fungal and bacterial universal primers. L1 - 100 bp DNA size marker, L2 - PCR amplification of ITS region with DNA extracted by Mannitol/CTAB method, L3 - PCR amplification of ITS region with DNA extracted by PEG/NaCl method, L4 - PCR amplification of ITS region with DNA extracted by SPB method, L5 - Lambda DNA cut with EcoRI/HindIII, L6 - PCR amplification of 16s rDNA with DNA extracted by Mannitol/CTAB method, L7 - PCR amplification of 16s rDNA with DNA extracted by PEG/NaCl method, L8 - PCR amplification of 16s rDNA with DNA extracted by SPB method, L9 - PCR amplification of 16s rDNA with DNA extracted by Norgen's kit

According to the current study, it was proved that the soil DNA isolated by protocol having mannitol was more effective than the other protocols tested. The protocol consists of mannitol in the lysis buffer to isolate DNA from bacterial and fungal mycelia. Moreover, an inclusion of mannitol with $\mathrm{NaCl}$ may promote cell disruption and removal of humic acid and other organic contaminants, the presence of which would have otherwise inhibited PCR reaction. Hence, the study confirmed mannitol/CTAB method provides DNA of sufficient quality and integrity to amplify the genetic regions, which may be provided a complete information and understanding of microbial biota. Further, it provides the quality DNA for downstream applications such as DNA cloning, sequencing and metagenomic studies needed for microbial community analysis. Therefore, the research findings would be helpful for soil ecologists and taxonomists to explore the composition and dynamics of microbial communities in paddy soil.

\section{CONCLUSION}

The results revealed that all three protocols used in the study are suitable for extraction of DNA from paddy soil. Comparatively direct DNA extracted using $\mathrm{PEG} / \mathrm{NaCl}$ method does not provided good quality DNA for downstream application. On the other hand, direct DNA extracted using Mannitol/CTAB method has resulted in higher quality DNA with a considerable yield and amplification of expected size PCR bands proving its suitability for downstream molecular applications. However, the DNA extracted using above three protocols co-existed with contaminants such as proteins and humic acids. Therefore, further optimizations and DNA recovery studies are required to obtain quality DNA with high quantity. Moreover, addition of more DNA purification steps prior to the PCR amplification would result in expected bands via removing of PCR inhibitors effectively.

\section{ACKNOWLEDGEMENTS}

Financial assistance by the National Research Council, Sri Lanka (Grant no. NRC T0-16-07) is acknowledged. Authors express gratitude to Dr. U.M.A. Kumara, Mr. Gamunu Wijesooriya and Mrs. C. Ranasinghe for their great support in research. 


\section{REFERENCES}

Avinash, N., Kunal, J, Shah A.R. and Madamwar, D. (2016). An efficient and cost-effective method for DNA extraction from a thalassohaline soil using a newly formulated cell extraction buffer. 3 Biotech. 6(1), 62. doi:10.1007/s13205-0160383-0.

Chen, H., Rangasamy, M., Tan, S.Y., Wang, H. and Siegfried, B.D. (2010). Evaluation of Five Methods for Total DNA Extraction from Western Corn Rootworm Beetles. PLoS ONE. https://doi.org/10.1371/journal.pone.0 011963.

Delmont, T.O., Robe, P., Clark, I., Simonet, P. and Vogel, T.M. (2011). Metagenomic comparison of direct and indirect soil DNA extraction approaches. Journal of Microbiological Methods. 86, 397-400.

Devi, S.G., Fathima, A.A., Radha, S., Arunraj, R., Curtis, R. and Ramya, M. (2015). A rapid and economical method for efficient DNA extraction from diverse soils suitable for metagenomic applications. PLoS ONE. 1-16. https://doi.org/10.1371/journal. pone. 0132441.

Dimitrov, M.R., Veraart, A.J., Hollander, M. De, Smidt, H., van Veen, J.A. and Kuramae, E.E. (2017). Successive DNA extractions improve characterization of soil microbial communities. PeerJ. 5:e2915 https://doi.org/10.7717/peerj. 2915.

Fatima, F., Pathak, N. and Verma, S. R. (2014). An Improved Method for Soil DNA Extraction to Study the Microbial Assortment within Rhizospheric Region. Molecular Biology International. DOI: 10.1155/2014/518960.

Frostegård, Å., Courtois, S., Ramisse, V., Clerc, S., Bernillon, D., Le Gall, F., Jeannin, P., Nesme, X. and Simonet, P. (1999). Quantification of bias related to the extraction of DNA directly from soils. Applied and Environmental Microbiology. 65(12), 5409-5420.

Gu, H.J., Li, Y. and Zhao, W. 2005. Comparison of methods of DNA extraction from paddy soil. Journal of Jiangsu University, 15, 300-305.

Islam, M.R., Trivedi, P., Palaniappan, P., Reddy, M.S. and Sa, T. (2009). Evaluating the effect of fertilizer application on soil microbial community structure in rice based cropping system using Fatty acid methyl esters (FAME) analysis. World Journal of Microbiology and. Biotechnology. 25, 1115-1117.

Islam, R., Sultana, T., Joe, M.M. and Cho, J. (2012). Comparisons of direct extraction methods of microbial DNA from different paddy soils. Saudi Journal of Biological Sciences, 19 (3), 337-342. https://doi.org/10.1016/j.sjbs.2012. 04.001 .

Knauth, S. and Schmidt, H. (2013). Comparison of commercial kits for the extraction of DNA from paddy soils. Letters in Applied Microbiology. 56(3), 222-228. https://doi.org/10.1111/ lam.12038.

Knietsch, A., Waschkowitz, T., Bowien, S., Henne, A. and Daniel, R. (2003). Metagenomes of complex microbial consortia derived from different soils as sources for novel genes conferring formation of carbonyls from shortchain polyols on Escherichia coli. Journal of Molecular Microbiology and Biotechnology. 5, 46-56.

Li, J., Li, B., Zhou, Y., Xu, J. and Zhao, J. (2011). A rapid DNA extraction method for PCR amplification from wetland soils. Letters in Applied Microbiology. 52(6), 626-633.

Liu, Y., Wang, P., Pan, G., Crowley, D. and Li, L. (2015). Functional and structural responses of bacterial and fungal communities from Functional and structural responses of bacterial and fungal communities from paddy fields following long-term rice cultivation. Journal of Soils and Sediments. 16(5), 14601471.doi.org/10.1007/s11368-015-1343-8.

More, M.I., Herrick, J.B., Silva, M.C., Ghiorse, W.C. and Madsen, E.L. (1994). Quantitative cell lysis of indigenous microorganisms and rapid extraction of microbial DNA from sediment. Applied and Environmental Microbiology. 60(5), 1572-1580.

Op De Beeck, M., Lievens, B., Busschaert, P., Declerck, S., Vangronsveld, J. and Colpaert, J.V. (2014). Comparison and validation of some ITS primer pairs useful for fungal metabarcoding studies. PloS ONE. 9(6), p.e97629. https://doi.org/10.1371/journal.pone.009762 9.

Philippot, L., Abbate, C., Bispo, A., Chesnot, T. and Hallin, S. (2011). Soil microbial diversity: an ISO standard for soil DNA extraction Soil microbial diversity: an ISO standard for soil DNA extraction. Journal of Soils and 
Sediments. 10(7), 1344-1345. https://doi.org/ 10.1007/s11368-010-0265-8.

Plassart, P., Thomson, B., Griffiths, R. and Dequiedt, S. (2012). Evaluation of the ISO Standard 11063 DNA Extraction Procedure for Assessing Soil Microbial Abundance and Community Structure. PLoS ONE. 7(9), e44279. https://doi.org/10.1371/journal. pone. 0044279 .

Robe, P., Nalin, R., Capellano, C., Vogel, T. M. and Simonet, P. (2003). Extraction of DNA from soil. European Journal of Soil Biology. 39(4), 183-190. https://doi.org/10.1016/S11645563(03)00033-5.

Saenz, J.S., Roldan, F., Junca, H. and Arbeli, Z. (2019). Effect of the extraction and purification of soil DNA and pooling of PCR amplification products on the description of bacterial and archaeal communities. Journal of Applied Microbiology. 126(5), 1454-1467.

Sambrook, J., Fritsch, E.F. and Maniatis, T. (1989). Molecular cloning: a laboratory manual. Cold Spring Harbor Laboratory Press, Cold Spring Harbor, New York, ISBN 0879695773.

Satyanarayana, S.D., Krishna, M.S.R. and Kumar, P.P. (2017). Optimization of high-yielding protocol for DNA extraction from the forest rhizosphere microbes. 3 Biotech. 7(2), 1-9.

Shao, W., Khin, S. and Kopp, W.C. (2012). Characterization of effect of repeated freeze and thaw cycles on stability of genomic DNA using pulsed field gel electrophoresis. Biopreservation and Biobanking. 10(1), 4-11.
Courtois, S., Frostegard, Å., Göransson, P., Depret, G., Jeannin, P. and Simonet, P. (2001). Quantification of bacterial subgroups in soil: comparison of DNA extracted directly from soil or from cells previously released by density gradient centrifugation. Environmental Microbiology, 3(7), 431-439.

Tsai, Y.L. and Olson, B.H. (1991). Rapid method for direct extraction of DNA from soil and sediments. Applied and Environmental Microbiology. 57, 1070- 1074.

Wichern, F., Islam, M., Hemkemeyer, M., Watson, C. and Joergensen, R.G. (2020). Organic Amendments Alleviate Salinity Effects on Soil Microorganisms and Mineralisation Processes in Aerobic and Anaerobic Paddy Rice Soils. Frontiers in Sustainable Food Systems. 4, p.30. https://doi.org/10.3389/fsufs.2020. 00030.

Yi, X., Yi, K., Fang, K., Gao, H., Dai, W., Cao, L. and Saleem, M. (2019). Microbial Community Structures and Important Associations between Soil Nutrients and the Responses of Specific Taxa to Rice-Frog Cultivation. Frontiers in Microbiology. 10, p.1752. https://doi.org/10.3389/fmicb.2019.01752.

Zhang, R., Cao, H., Cui, Z., Li, S. and Fan, B. (2003). Extraction and purification of soil microbial total DNA. Acta Microbiologica Sinica. 43(2), 276-282.

Zhou, J., Bruns, M. A. N. N. and Tiedje, J. M. (1996). DNA Recovery from Soils of Diverse Composition. Applied and Environmental Microbiology. 62(2), 316-322. 